\section{Acordos de acionistas no Direito Brasileiro}

Guiomar T. Estrella Faria

Professora de Direito Comercial da Faculdade de Direito da UFRGS

e da Escola Superior da Magistratura, Chefe do Departamento de

Direito Privado e Processo Civil - UFRGS

SUMÁRIO

Introdução; $1^{\mathbf{1}}$ Parte: $\mathrm{O}$ acordo de acionistas no plano teórico; a) Histórico; b) Caracterização; $2^{\mathbf{2}}$ Parte: $\mathrm{O}$ acordo de acionistas no moderno Direito Brasileiro; a) Natureza dos Acordos de Acionistas; b) Espécies de Acordos de Acionistas; c) Modalidades de Acordos de Acionistas; d) Conteúdo dos pactos do acionariado; e) Vantagens do acordo de acionistas sobre outros pactos de formação de controle: boldings e sindicatos de ações.

\section{Abstract}

The present paper studies the "Acordos de Acionistas" - sharebolders' agreements - as they are regulated in the Brazilian Company Act of December 16, 1976. It is the outcome of a preeminently bibliographical research, due to the fact that it's subject is relatively new in our country's legislation, in spite of it's baving been discussed for many decades now, since sbarebol der's agreements were introduced and became more and more important in companies' lives all over the country. Like other institutes in Commercial Law, shareholders' agreements were introduced in statute after baving enjoyed widespread aceptance for along time: practice induced legislation.

In foreign Law these agreements, being strictly private and para-social contracts, do not bave binding force except for the contracting shareholders, and are accordingly ignored by the compa ny. Brazilian Company Act, in contrast, explicitly extends their effects to the company, provided that the document is deposited in its archives. Besides, Brazilian shareholders' agreements go farther than the institution of a voting trust, even if they do not amount the constitution of a bolding company.

\section{Introdução}

No presente trabalho estamos nos propondo um exame dos Acordos de Acionistas das Sociedades por Ações.
Não nos vamos ocupar dos acordos de quotistas, embora já bastante comuns na nossa atividade - geralmente pactuados para harmonizar previamente grupos antagônicos, com participações societárias equivaentes, cujas vontades é necessário harmonizar, na votação dos grandes interesses sociais. Não os abordaremos porque sendo restrito o acesso aos Mercados de Capitais, aos títulos de emissão das Companbias bertas, as sociedades por quotas de responsabilidade limitada são de pequeno interesse para nossa disciplina Instituigóes Financeiras.

Nossa pesquisa foi, na sua essência, bibliográfica, pois o tema é relativamente novo na legislação, embora a discussão doutrinária lhe fosse anterior, já que, como geralmente ocorre com a denominada matéria mercantil, os fatos atropelaram o direito e assim esses acordos vinham sendo celebrados, há bastante tempo.

Parece-nos desnecessário insistir na importância desses pactos parassociais, de que pode depender a própria vida da sociedade a realização do seu objeto social.

Pretendemos não só caracterizá-los, como fixar os limites jurídico-legais à autonomia da vontade dos acordantes, reservando a tais institutos o seu verdadeiro papel de ativadores da vida e dos negócios das sociedades, e não de meros instrumentos de exercício do poder oligárquico de controladores. $1^{\text {a }}$ Parte

O acordo de acionistas no plano teórico

a) Histórico

A Regulamentação, através do artigo 118 e seus $\S \S$, da Lei no 6.404/76, do Acordo de Acionistas, incorporou ao nosso sistema legal um instituto já conhecido do direito societário brasileiro.

Embora não previstas pelo Decreto-Lei no $2.627 / 40$, as convenções entre acionistas sobre o exercício do direito de voto e a alienação das respectivas ações ocorriam com certa frequêencia, dando origem a longas discussões doutrinárias.

Contra os mesmos foi alegada a violação da norma de ordem pública, que assegura aos acionistas o pleno exercício do direito de voto, o qual compreende também o direito ao debate prévio nas assembléias.

Segundo esse entendimento, o acordo que determinasse aos acionistas firmatários, como deveriam votar, cercearia o exercício do direito de debater as questões em assembléia ${ }^{1}$.

Já outros consideravam apenas vedados os acordos permanentes, que implicariam renúncia definitiva ao direito de debater ${ }^{2}$.

Outros autores entendiam, ainda, fazer parte do direito de voto, também o direito de dispor do mesmo, celebrando os acordos com outros acionistas. Também consideravam a hipótese de quebra do acordo, que acarretaria ao acionista apenas o dever de indenizar os demais por perdas e danos ${ }^{3}$.

De qualquer forma, os acordos continuaram sendo celebrados, instalando-se inclusive o costume de fazê-los arquivar pela companhia ${ }^{4}$.

Diante dessa realidade, optaram os auto res do projeto - que resultou na Lei $\mathrm{n}^{\circ}$ 6.404/76 - introduzir o instituto do acordo de acionistas naquele texto, e o fizeram como alternativa à holding $\mathrm{e}$ ao acordo ocul to 5 .

Os comentaristas têm assinalado a importância da introdução do instituto no direito brasileiro, destacando-lhe, inclusive um papel vivificador do direito acionário ${ }^{6}$.

\section{b) Caracterizaşãa}

Segundo a maior parte dos autores, que, entre nós, se têm detido no exame desta categoria especial de negócio jurídico, os acordos de acionistas são contratos, já que resultam de deliberações de vontade e têm por objeto criar e/ou modificar relações jurídicas entre as partes acordantes, que se obrigam a cumprir o estatuído e adquirem, em razão do mesmo, o direito de, também reciprocamente, se demandarem o cumprimento ou as sanções ao inadimplente.

Já não é tão pacífica a qualificação civil ou comercial, o que, num primeiro momento, poderia parecer desprovida de interesse maior, já que, em princípio, as normas do direito civil, disciplinadoras das relações entre as partes contratantes, informam também os contratos comerciais, aplicando-se as normas comerciais, aos casos expressos, previstos nas leis específicas.

Esta qualificação - civil ou comercial adquire relevância, no entanto, face a outra divergência doutrinária sobre serem esses pactos parassociais ${ }^{7}$ ou intra-societários ${ }^{8}$ pois é evidente que, sendo considerados intra-societários, seguem a qualificação da norma principal que rege a companhia, que é sempre mercantil (Lei $\mathrm{n}^{\circ} 6.404 / 76$, art. $2^{\circ}$, $\S 1^{\mathrm{o}}$ ).

A despeito de toda a argumentação em contrário de autores com o peso e a autoridade de um Carvalhosa ou de um Comparato, entendemos, como Lamy Filho e Bulhões Pedreira, que os Acordos de Acionistas integram o direito societário (pelo menos no direito brasileiro, como veremos mais extensamente na $2^{\underline{3}}$ Parte deste trabalho).

Outra discussão travada na doutrina ver sa sobre a tipicidade ou não desses contratos.

Autores há que os consideram negócios perfeitamente tipificados em lei e também ali regulamentados', enquanto outros os consideram uma categoria que compreende diversos negócios diferentes entre $\mathrm{si}^{10}$, não havendo nas normas que os regulam regras que os uniformizem, impondo característi-

\footnotetext{
68 R. Fac. Direito UFRGS, Porto Alegre, 10: 68-78, jul. 1994
} 
cas próprias e lhes estabelecendo formalidades especiais, salvo o arquivamento, que não lhes altera a estrutura, nem modifica as relações entre as partes.

Partilhamos desta última posição.

Para convalidar as afirmações anteriores, basta-nos examinar as espécies de acordos assinaladas por todos os comentaristas e já noticiadas na doutrina estrangeira e no nosso direito anterior.

A maior parte dos autores distingue os acordos de acionistas em acordos de bloqueio e acordos de comando; aqueles seriam os que determinam o bloqueio ou proibição $\mathrm{da}$ venda das ações dos convenantes, enquanto os acordos de comando seriam os que fixam regras restritivas ao direito de voto, determinando como deverão os convenantes exercê-lo, em ocasiões e sobre matérias pré-fixadas.

Alguns autores ainda destacam a existência de acordos consorciais, quando os convenantes fixam objetivos coletivos ou comuns, por exemplo, o controle da companhia, enquanto outros acordos seriam de prestações, porque as estabeleceriam recíprocas, em direitos e obrigações entre as partes.

Só esta grande variedade de negócios, que podem ser objeto de acordos de acionistas, nos parece suficiente para descartar a tipicidade pretendida, pois cada um daque les pactos terá regras próprias, distintas da que vierem a reger os demais.

Isto sem considerarmos que dificilmente encontraremos um Acordo de Acionistas que contenha apenas um só daqueles negó cios, mas, bastante freqüentemente os teremos com objetivos de bloqueio, comando, consorciais e de prestações, num único convênio.

Também assinala a doutrina a distinção entre acordos unilaterais, bilaterais e plurilaterais.

Seriam unilaterais os acordos de acionistas que impusessem deveres ou restrições ao exercício de direitos para uma das partes convenantes, apenas, pelo que ficaria a outra parte beneficiada com tais restrições imposições, dependendo da faculdade de opção: ou seja, do grau de autonomia da vontade das partes obrigadas - principalmente do seu poder econômico - (tais acordos poderiam vir a ser anulados, em juízo, por vício de vontade do acordante e ainda abuso do poder econômico ou de posição dominante).

São bilaterais os acordos que estabelecerem reciprocidade nas posifóes $e$ interesses das partes convenantes, pouco importando para tal caracterização o número de participantes de um ou de outro lado, pois o caráter bilateral é fornecido exatamente pela existência de blocos de acionistas, em dois pólos de interesses divergentes.

É importante esta caracterização, pois tais acordos vão seguir as regras dos negócios jurídicos bilaterais, com destaque especial para o inadimplemento, que no regime estatuído pelo artigo $118, \S 3^{\circ}$, poderá levar à execução judicial específica das obrigações assumidas, não se resolvendo, portanto, simplesmente em perdas e danos, conforme regra geral do direito civil.

Acordos plurilaterais, por sua vez, seriam aqueles, nos moldes da tradicional figura delineada por Ascarelli, para caracterizar $o$ ato constitutivo das sociedades, decorrentes de um som rcordos de acionistas acordos de acionistas para obtenção e conservação do controle das companhias.

Outro tema bastante discutido na doutrina diz respeito à natureza, a essência jurídica, desses acordos.

Autores há que os consideram constitutivos de verdadeira sociedade civil ${ }^{11}$, a que faltariam, no entanto, o aporte de capitais e esforços, além de que as sociedades (pelo menos em nosso direito) são negócios jurídicos formais, que dão origem a um ent autônomo, dotado de personalidade jurídica própria - desde que inscritos no registro respectivo. Ora, os acordos de acionistas são informais, não há aportes de capitais nem de serviços, bem como não originam a criação de outra sociedade, anexa à companhia.

Por outro lado, o arquivamento na sede da companhia objetiva, apenas, tornar a convenção observável pela sociedade, não tem o condão de substituir o ofício público registral, para os efeitos do artigo 18 do Código Civil.

Já para outros autores, o acordo de acionistas, embora não prefigurando o controle da sociedade, poderia ser considerado como associação, porque, como esta, não tem finalidade lucrativa ${ }^{12}$

Valem para a concepção associativa as mesmas objeções opostas à societária - pois, na verdade, em qualquer das duas hipóteses haveria o necessário aporte de esforços e recursos e um novo ente seria criado, o que não ocorre num acordo de acionistas.

Outra concepção assemelha os acordos de acionistas às sociedades controladoras ou boldings.

No direito europeu e no direito americano em que o acordo de acionistas (sindicato, naquele ou voting trust, neste) implica, ou transferência total das ações, ou de parte dos direitos a elas inerentes, para os dirigentes do sindicato ou trustees, dos voting trust, há uma maior aproximação da bolding que, de qualquer forma, ainda é bem distinta, pelo seu caráter permanente e de controle total sobre a companhia, que tem as suas ações vinculadas ao sindicato ou voting trust.

De qualquer forma, o acordo de acionistas, mesmo com as características acima apontadas, que lhe foram dadas no direito estrangeiro, tem sobre a constituição da bolding a vantagem inconteste de ser sempre temporário e ter objeto definido no instrumento negocial, não representando, portanto, o controle absoluto da sociedade.

No direito estrangeiro, os acordos, por serem negócios estritamente privados e parassociais, vinculam apenas os signatários, isto, nos países onde são tolerados, pois em alguns são considerados nulos, posição cada vez mais rara e bastante contestada na doutrina ${ }^{13}$.

Também há consenso na doutrina internacional que tais pactos devam ser celebrados por prazo determinado, para que não representem renúncia a direito essencial do acionista, o voto, o que cominaria de ilicitude o seu objeto.

Em conclusão, podemos afirmar, com tranqüilidade, a tendência, cada vez maior, na doutrina e na jurisprudência internacionais, a admitir a validade desses pactos, à medida que restriçōes vão cedendo à realidade do aumento considerável da prática dessas convenções. É o velho modo de formação consuetudinária do direito comercial, sempre presente, exercendo sua força geradora de normas, que acabam incorporadas em leis.

\section{2a Parte}

$O$ acordo de acionistas no moderno

Direito Brasileiro

O legislador brasileiro de 1976 assumiu posição de vanguarda, face aos demais sistemas jurídicos vigentes, ao reconhecer expressamente a validade dos acordos de acionistas, estabelecendo normas reguladoras do instituto, no seu artigo 188 e $\S \S$.

$\mathrm{Na}$ exposição de motivos, assim se expressaram os redatores do Projeto:

"... modalidade contratual de prática intensa, mas que os códigos teimam em ignorar... figura jurídica da maior importância para a vida comercial... como alternância à bolding (solução buscada por acionistas que pretendem o controle pré-constituído, mas que apresenta os inconvenientes da transferência definitiva das ações para outra sociedade) e ao acordo oculto e irresponsável (de eficácia duvidosa em grande número de casos) cumpre dar disciplina própria ao acorde acionistas..."14

Segundo os mesmos autores do projeto, apesar de inspiradas no debate entre os juristas estrangeiros e no estudo comparado das leis vigentes em outros países, as normas inseridas sobre o instituto, no direito brasileiro, apresentam características que devem ser examinadas para que possa ser compreendido, em toda sua extensão ${ }^{15}$.

$\mathrm{Na}$ verdade, os acordos de acionistas, no direito brasileiro, em relação aos similares, 
do direito estrangeiro têm as seguintes características:

a) são expressamente reconhecidos e têm sua eficácia assegurada, tanto entre os convenantes, como pela própria companhia;

b) são incorporados aos demais institutos ptóprios da companhia;

c) não se resolvem em perdas e danos, como previsto no direito das obrigações para o inadimplemento, mas são passíveis de execução específica;

d) obrigam a companhia à sua observância, quando devidamente arquivados ${ }^{16}$.

Essas características apontadas levaram os dois autores do ante-projeto a assegurar ter a lei incorporado ao sistema acionário "um mecanismo complementar de organização da vida societária, válido e eficaz perante terceiros e a própria companhia ${ }^{17}$.

Já na vigência do Decreto-Lei $\mathrm{n}^{\text {o }}$ $2.627 / 40$, esses dois autores vinham publicando artigos e fazendo conferências em que propunham a adoção do instituto no direito brasileiro ${ }^{18}$, no que apenas seguiam a orientação dominante na doutrina, amplamente favorável às convenções de voto ${ }^{19}$.

Uma preocupação sobressaía no consenso de aceitação dos acordos de acionistas e está presente na maior parte dos autores, condicionando a validade dessas convenções aos interesses da companhia e, desde que não firam os direitos dos acionistas minoritários ${ }^{20}$.

No Brasil, como no exterior, os costumes do acionariado, de certa forma, vieram a formar a opinião dos juristas e informar as decisões da jurisprudência, de que se logrou o acatamento do ante-projeto e das razões aduzidas na exposição de motivos, com aprovação pelo Congresso Nacional e sanção do Presidente da República, em 15 de dezembro de 1976, e, finalmente, entrada em vigor, em 17 de dezembro de 1976, da Lei $\mathrm{n}^{\circ} 6.404$, que, no seu artigo 118 , rege as convenções entre acionistas, denominadas de acordos de acionistas.

Com essa promulgação, o direito brasileiro deixou para trás, definitivamente superadas, as discussōes ainda hoje travadas, no direito estrangeiro sobre a licitude, a va- ciais, como até, as mais das vezes, considerados anti-societários.

$O$ direito brasileiro reconheceu a legitimidad dos acordos, garantiu sua eficácia entre as partes convenantes e até perante a companhia e terceiros, assim como regulou o exer cício do controle, inclusive através de acordo de acionistas, direitos que são oponívei aos demais sócios, dentro da sociedade, da mesma forma que os acordos de voto só podem ser cumpridos nas assembléias gerais da companhia.

Reforça o acima argumentado a seguint afirmação da Fábio Konder Comparato:

"O direito de voto entende com o próprio funcionamento da sociedade por ações e con titui um modo de atuaşão sobre o patrimônio social $^{\prime 25}$ (grifamos)

Também improcede o argumento de serem os acordos de acionistas estranhos a direito societário, porque regidos pelo direito comum das obrigações, já que muitas outras relações jurídicas de direito societário também se regem pelo direito civil, pois este informa todos os negócios privados até públicos. (capacidade das partes, licitude do objeto, formalidades prescritas para só lembrar os mais óbvios - são requisitos de qualquer negócio). Por outro lado, os princípios, que informam o direito da obrigações (autonomia da vontade, boa-fe, teoria da imprevisão, etc.) também são observados nos negócios societários.

Ainda o fato de ter a pessoa jurídica uma dinâmica própria, na sua ordem interna, que nada tenha a ver com o disposto no acordo de acionistas ${ }^{26}$, não oferece sustentação ao argumento da parassocialidade do "acordos de acionistas", uma vez que no nosso direito, eles estão previstos e regulados, em sua maior parte na norma legal de que emana "a lei interna da sociedade" (estatuto) que no dizer de Carvalhosa "tem su dinâmica própria" ${ }^{127}$.

b) Espécies de Acordos de Acionistas

O direito brasileiro prevê, no caput do artigo 118 , da Lei $n^{\circ} 6.404 / 76$, duas espécie de acordos de acionistas: as convenfóes de voto e as convengóes de bloqueio.

As convenções de voto são aquelas pelas quais os acionistas se comprometem, prévia e formalmente, a votar da mesma forma, num determinado sentido, ou sobre certas matérias.

São também convençōes de voto aquelas organizadas para garantir poder de decisão permanente nas assembléias, ou seja, o controle da sociedade (art. 116, caput).

As convenções de voto são as mais controvertidas dentre os acordos de acionistas: elas também são responsáveis pelo maior número de argumentos contrários à validade desses pactos, porque "representariam o cerceamento do exercício de direito essencial de acionista".

Ora, tais direitos não podem ser objeto de convenção que restrinja seu exercício (art. 109, caput). Em razão desse dispositivo, que incorporou princípio tradicional do direito societário, entendem certos autores serem inválidos os acordos de acionistas, com convenções de voto, uma vez que o direito ao voto compreenderia direito ao debate prévio, em assembléia, o que não ocorre com o acordo, já de antemão, regulamentado.

Mesmo na vigência do Decreto-Lei $2.627 / 40$, isto é, antes do reconhecimento legal dos acordos de acionistas, já a doutrina concluira que nulas seriam, apenas, as cláusulas que importassem em renúncia definitiva ao direito de voto ${ }^{28}$

Também tiveram sua validade discutida os acordos de voto para garantir o controle da companhia ${ }^{29}$, sob a alegação de, eventualmente, cercearem os direitos dos minoritários $^{30}$, ou estabelecerem controles abusivos.

Nesta hipótese, já não se cogita apenas da ofensa à lei especial, porquanto a lesão a direito alheio, implicando no dever de indenizar, ensejaria a aplicação do direito comum e ação de apuração das perdas e danos.

Além das convenções de voto, os acordos de acionistas podem conter convenções de bloqueio, sobre a compra e venda de ações e/ou a renúncia à preferência para subscrever ou adquirir ações. 
É mais pacífica a doutrina quanto a esta espécie de acordos, até porque sendo da natureza das companhias a livre negociação das ações, ninguém contestaria estivesse contida, nesta liberdade maior, a faculdade menor de transacionar sobre tal negociação. Não podem, por outro lado, as partes esquecer, na celebração dessa espécie de acordos, que os bloqueios, nas companhias fechadas, deverão atender ao disposto no artigo $36 \mathrm{~d}$ lei societária, enquanto nas companhias abertas, uma vez que o disposto no artigo citado, restringindo às companhias fechadas o direito de reduzir a circulação das ações, parece vedar esses acordos às companhias abertas. No entanto, alguns autores entendem que as disposições do $\S 4^{\circ}$ do artigo 114, retirando as ações do mercado, praticamente admite tais acordos, também, nas companhias abertas.

Poder-se-ia alegar estivesse o legislador neste dispositivo a referir-se a outras espécies de acordos, e não ao de bloqueio. Prevalecerá sempre sobre tal conjectura o argumento de que ubi lex non distiguit..

Certamente foi esse o raciocínio que levou Carvalhosa a afirmar serem tais acordos

"Modalidade legítima de contornar a proibição legal de constar do estatuto limitação dessa ordem" ${ }^{131}$.

c) Modalidades de Acordos de Acionistas

Os acordos de acionistas poderão ser unilaterais, bilaterais, ou plurilaterais, isto é quanto à posição assumida pelas partes convenantes, em direitos e obrigações, reciprocamente, assim como em qualquer outro pacto ou contrato.

São unilaterais os acordos que estabelecem compromissos a uma única das partes - como por exemplo, a preferência estatuída no acordo oferecida pelo controlador aos minoritários, para aquisição das ações de controle, ou vice-versa.

São bilaterais os acordos sinalagmáticos, com obrigações e direitos firmados entre as partes, em recíprocas verdadeiras - relaçōes biunívocas - por exemplo, se na hipótese anterior houvesse também obrigação dos signatários minoritários de oferecerem suas ações ao controlador e vice-versa.

Finalmente serão plurilaterais os acordos em que todas as partes objetivam e se obrigam a votar no sentido de proteger, buscar ou manter certas prerrogativas: controle, proteção das minorias, etc.

\section{d) Conteúdo dos Pactos do acionariado}

A Lei no $6.404 / 76$, no seu artigo 118 , ao disciplinar os acordos, estabelece, em linhas gerais, que tais pactos versarão sobre compra e venda de aşões, preferência para adquiri-las e direito de voto.

A lei societária não especifica, mas é óbvio que, sendo um negócio jurídico, o acordo de acionistas está sujeito às normas gerais do artigo 82 do Código Civil, requerendo agente capaz, objeto lícito e forma prescrita ou não defesa em lei.

Vamos examinar, embora com a brevidade requerida, cada uma dessas exigências legais:

Agente capaz - não sendo sociedades de pessoas, as companhias podem ter, em seus quadros acionários, menores púberes e até impúberes, que, ou serão assistidos, ou simplesmente representados, por seus pais ou tutores, no exercício dos seus direitos sociais, os quais gerem seus patrimônios, em decorrência do munus ou do pátrio poder. Estariam tais deliberações, quaisquer delas, compreendidas nos poderes de gestão do bonus pater familiae? Nossa jurisprudência tem sido rigorosa, no sentido de exigir al vará judicial para alienações patrimoniais vultosas - principalmente de imóveis -; entendemos que, se tais acordos implicarem possibilidade de prejuízo substancial ao patrimônio dos menores - mesmo em se tratando de bens móveis, como as ações - seria prudente - para obviar os prejuízos, não só aos menores-acionistas, mas também, aos demais e à própria companhia, pela eventual nulidade do negócio - fosse o mesmo cercado de todas as precauções, não só jurídico-legais, como econômicas.
Quanto à licitude do objeto - é preciso não esquecer que se trata de negócio vinculado à sociedade, não podendo, portanto, conflitar com o objeto social da companhia, mais ainda, deverá propiciar-lhe melhores condições de efetivação. Também não pode, evidentemente, o acordo consagrar abusos do direito, nem dos controladores, nem dos minoritários.

Também são unânimes os autores, no sentido de que o objeto do acordo seja completamente definido, inadmitindo-se acordos genéricos, bem como acordos que contenham prestasão de verdade, como por exemplo, compromisso de aprovar contas.

São óbvias essas vedaçōes, uma vez que restrições ao exercício de direitos devem ser explícitas e claras, para não importarem em renúncias, nulas de pleno direito.

Quanto à forma, embora a lei não a prescreva, é presumida a obrigatoriedade da forma escrita para os efeitos do caput do artigo 118.

e) Vantagens do acordo de acionistas sobre outros pactos de formasãa de controle:

"boldings" e sindicatos de açóes

Os acordos de acionistas, como bem propuseram os autores do ante-projeto, representam uma forma intermediária entre a bolding $\mathrm{e}$ os acordos informais ${ }^{32}$, e ainda apresentam outras vantagens.

Acordos de acionistas e bolding - constituem as sociedades controladoras ou "boldings" pessoas jurídicas comerciais, não necessariamente sociedades por ações, que detêm em outras sociedades, denominadas controladas, participações acionárias, que lhes garantem, nos termos do artigo 116 da Lei $n^{2}$ 6.404/76, o controle da companhia.

Já da própria noção de holding, transparece a maior vantagem dos "acordos de acionistas" sobre aquela, que é a transferência da propriedade das ações dos contratantes, para a pessoa jurídica controlante, o que não ocorre na simples convenção de voto, quando, apesar de todas as cláusulas limitativas, o voto e outros direitos de sócio são exercidos pelos próprios acionistas firmatários.

Ainda é importante destacar que a constituição da sociedade holding vai representar para os acionistas, desejosos de conservar o controle da S/A em mãos de grupo definido, um montante de despesas com registros, publicidade, pessoal - mesmo que não se dê à bolding a forma jurídica da companhia que um simples acordo de acionistas não irá gerar.

Ainda é interessante acentuar as vantagens dos acordos de acionistas sobre os sindicatos de voto - do direito europeu continental - e os voting trusts - do direito anglo-americano - embora estes institutos não sejam comuns no direito brasileiro, já que não previstos em lei; ficando, portanto, na esfera da autonomia da vontade das partes.

Os acordos de voto com constituição de mandatário - sindico ou trustee - para exercer aquele e outros direitos dos acionistas - têm sido alvo de severas críticas da doutrina, pela dissociação entre o exercício dos direitos às mesmas inerentes e a propriedade das ações, durante o prazo determinado no acordo.

Ora, nos acordos de acionistas do direito brasileiro, não foi prevista a figura do executor do acordo, embora não esteja proibi$\mathrm{da}^{33}$, como também não é proibida a delegação do exercício do direito de voto, (art 126 , $1^{\circ}$ ), desde que não seja em caráter permanente. O dispositivo, aqui mencionado, estabelece o prazo-limite para acordos de acionistas, que, eventualmente, envolvessem a transferência do direito de voto.

Tais convençōes, afora a desvantagem de constituírem agentes fiduciários de acionistas, não-previstos na lei, ainda trariam aos convenantes, afora a desvantagem da transferência do exercício de voto, a necessidade de refazer anualmente os pactos.

\section{f) Prazo de Duração}

Embora a lei não fixe prazos-limites para a duraça dos acordos de acionistas, é contrária a toda tradição do nosso direito a vinculação perpétua ou de muito longa dura- 
ção, principalmente quando a avença firmada represente cerceamento ao exercício de direitos (voto, disposição do patrimônio e outros correlatos).

Pactuados por prazo indeterminado, estarão sujeitos às normas gerais dos contratos: podem ser denunciados por qualquer das partes.

No direito estrangeiro existem parâmetros, indicados pela tradição, que fazem oscilar esses prazos entre 03 (três) e 10 (dez) anos, e ainda a orientação de que sejam os prazos inscritos nos contratos, para evitar as denúncias unilaterais ${ }^{34}$.

\section{g) Execusão Específica das Obrigaşões} oriundas dos Acordos de Acionistas

O artigo 118 da Lei nº 6.404/76 prevê, no seu $\S 33^{\circ}$, a execução específica das obrigações assumidas, nos termos dos artigo 632 a 641 do Código de Processo Civil

Não é simples a solução apontada pelo legislador, embora objetivasse o cumprimento do estipulado no contrato - o que não ocorreria na solução apontada na tradição do nosso direito a equivalência indenizatória ${ }^{35}$ - pois, como bem destacam os comentaristas, avenças há, que, em razão da natureza das obrigações, que delas se originam, e da especificidade das respectivas prestações, não podem ser objeto de execuçoes especificas ${ }^{36}$.

Estão neste caso os acordos de bloqueio que têm por objeto a preferência na subscrição de ações, pela simples razão de que a prestação só se tornaria exigível no momento em que houvesse oferta de ações.

Já no contrato de opção - verdadeiro pré-contrato, já existe promessa unilateral formal, do ofertante, de dispor das ações, se a outra exercer a opção.

Neste caso, pode ser exigido o cumprimento através da execução específica (CPC, art. 639).

No caso do acordo de votos, será obtida a execução, através da prestação jurisdicional substitutiva da vontade do inadimplente, nos termos do artigo 641 do Código de Processo Civil.
O título executivo será a ata da assembléia geral, comprobatória do inadimplemento do acionista, que violou a convencão.

$\mathrm{Nem}$ todas as questões que se possam originar do acordo de acionistas, é óbvio, ficarão resolvidas no processo de execução: as questões de direito material relativas a fundo e forma do convênio, validade, legitimidade de partes, etc., sempre poderão ser argüidas e questionadas pelas vias ordinárias.

A discussão de todas as hipóteses excedeia às dimensōes genéricas propostas a este trabalho.

\section{Conclusão}

Os Acordos de Acionistas, introduzidos formalmente no direito brasileiro pela Lei no 6.404/76, num pioneirismo sem precedentes, na história do moderno direito societário, pelas vantagens oferecidas, principalmente na organização e manutenção do controle acionário estão "entre aqueles negócios que o nosso ordenamento jurídico reconhece, por reputar sua função como socialmente transcendente e digna de ser protegida"37.

Apesar da recepção positiva, por parte de juristas - tanto na doutrina como na jurisprudência - bem como no meio dos negócios, isto é, do próprio empresariado, não perderam ainda as convenções de voto o seu caráter de instituto novo, que se vai adaptando às instituiçōes vigentes e também às mudanças das estruturas econômicas, em que vão ser implantados e instituídos.

Estas considerações são suficientes - poderiam ser alinhadas outras tantas - para evidenciar que, a todo momento, estarão surgindo novas questões que fazem dos Acordos de Acionistas um tema permanente de pesquisa, ao qual estarão, certamente, voltando os estudiosos.

\section{Notas}

Carlos Fulgêncio da Cunha Peixoto, Sociedade por Asốes, (5 vol.), II vol., Saraiva, São Paulo, 1972, págs.
354 e segs.
2 Traiando de Miranda Valverde, Sociedade por Acóes, $2^{2}$ ed., vol. II, Forense, Rio, 1953, págs. 58 a 63.

${ }^{3}$ Pontes de Miranda, Tratado, vol. 50, págs. 302 e segs. e págs. 395 e segs.

${ }^{4}$ Modesto Carvalhosa, Comentários a Lei das Sociedades Anônimas, (4 vol.), $4^{\circ}$ vol., Saraiva, São Paulo, 1977, págs. 140 e 141

${ }^{5}$ Lei no 6.404/76, Exposição de Motivos, Seção V.

6 Fábio Konder Comparato, O Poder de Controle da Sociedade Anônima, $3^{z}$ ed., Forense, Rio, 1983, (pág. 176).

7 V. Modesto Carvalhosa, op. cit., pág. 149 e segs.; idem, idem Acordo de Acionistas, Saraiva, São Paulo, 1984, pág. 37; tb. Fábio Konder Comparato, Novos Ensaios e Pare ceres de Direito Empresarial, Forense, Rio, 1981, pág. 76. 8 Alfredo Lamy Filho, José Luiz Bulhões Pedreira, $A$ Lei das S.A., Renovar, Rio, 1992, págs. 515 e seguintes. 9 Celso de Albuquerque Barreto, Acordo de Acionistas, Forense, Rio, 1982, pág. 37.

${ }^{10}$ Lamy Filho e Bulhōes Pedreira, op. cit., pág. 513.

11 Joaquim Garrigues e Rodrigo Uria, Comentarios a la Ley de Sociedades Anónimas, Ed. Aguirre, Madri, 1976, vol. I, pág. 665.

12 V. Antonio Pedrol, La Anónima Actual y la Sindicación de Acciones, Ed. Rev. de Derecho Privado, Madrid, ción de Acciones, Ed. Rev. de Derecho Privado, Madrid, 1969, pág. 39; v. tb. Gastone Cottinf, Le Convenzione
di Voto nelle Societa Conmerciale, Giuffrè, Milano, 1958, pág. 203.

13 O direito francés passou do Decreto-lei de 31.08.1937, que os considerou nulos, a admitir sua 24.08.1966). Moviso (art. So da Lei no 66.537, de 24. vigência do Codigo di Commercio, unanimidade na vigencia do Cojgo di Conicacio de 1942 jurisprucontra validade, apó a un mais favoráveis; Alemanha Sêcia éustria - favoráveis; Portugal e Espanta contra e doutrina, aos poucos, favorável; Inglaterra e Estados e doutrina, aos poucos, lavoravel; Inglaterra e Estado Anes de Azevedo, Sindicato de Votos, Livr. Athena, Porto, 1974, págs. 5 a 25.

14 Lei das Sociedades por Aşôes e do Mercado de Valores 14 Lei das Sociedades por Aşoées e do Mercado de Valores Molitiários, org. por Walter
Porto Alegre, 1977, pág. 49.

${ }^{15}$ Alfredo Lamy Filho e José Luiz Bulhōes Pedreira, $A$ Lei das S.A., Renovar, Rio, 1992, pág. 514.

16 Lamy Filho e Bulhões Pedreira, op. cit., págs. 515-6.

17 Lamy Filho e Bulhões Pedreira, op. cit., pág. 516.

${ }^{18}$ V. Lamy Filho, Rev. de Direito Mercantil, no 7, págs. 23 e segs., v. tb. idem, idem, Rev. Forense, Jul/Set 1973 v. 243 , págs. $37-42$

19 V. Valverde, Cunha Peixoto, Pontes de Miranda, op. loc. cit., notas 1,2 e 3 . Poderíamos alinhar outro tantos autores com posição idêntica e dezenas de dec sōes.

$20 \mathrm{~V}$. Valverde, op. loc, cit
Carvalhosa, Acordo de Acionistas, cit. pág. 31.

2 Lamy Filho e Bulhões Pedreira, op. cit., pág. 511.

${ }^{23}$ V. Comparato, Novos Ensaios, pág. 75; Egberto Lacerda Teixeira, José Alexandre Tavares Guerreiro, Das Sociedades Anônimas no Direito Brasileiro, Buschatsky Ed., São Paulo, 1979, págs. 303 e segs.

24 Carvalhosa (Acordos de Acionistas) menciona e se apóia na argumentação de Giorgio Oppo.

5 Comparato, Novos Ensaios, cit. pág. 81.

26 V. Carvalhosa, Acordo, cit. pág. 43.

27 Carvalhosa, Acordo, cit. pág. 43.

Valverde, op. cit., pág. 61.

29 Também denominados "Acordos de mando".

30 Carvalhosa, Comentários, cit. pág. 150.

31 Acordos, cit. pág. 143

32 Lei das S.A., cit. loc, cit. nota 14

33 Carvalhosa, Acordo de Acionistas, cit., pág. 109.

34 Carvalhosa, Acordos, págs. 200 a 204.

35 José Alexandre Tavares Guerreiro, Execuçāo Específica do Acordo de Acionistas, in R.D.M., São Paulo, 1981, no 41, págs. 40 e segs.

36 Carvalhosa, Acordo, págs. 259-260

\section{Bibliografia}

Azevedo, Amândio de; Sindicatos de Voto, Livr. Athena, Porto, 1974.

Barreto, Celso de Albuquerque; Acordo de Acionistas, Forense, Rio, 1982, (91 págs.).

Bataller. Carmen Alborgh; El Derecbo de Voto del Acio nista, Ed. Tecnos, Madrid, 1977.

Carvalhosa, Modesto; Acordo de Acionistas, Saraiva, São Paulo, 1984, (279 págs.).

Comentários à Lei de Sociedades Anônimas, $4^{\circ}$ vol., Saraiva, São Paulo, 1977, (313 págs.).

Comparato, Fábio Konder; Direito Emmpresarial, Saraiva, São Paulo, 1990, (págs. 174 a 180).

Novos Ensaios e Pareceres de Direito Empresarial, Forense, Rio, 1981, (págs. 52 a 87).

Poder de Controle na Sociedade Anônima, Forense, Rio, 1983 (págs. 176 a 195).

Cottino, Gastone; Le Convenzioni di Voto nelle Societd Conmerciali, Dott Giuffrè, Milano, $1958 \quad(302$ págs.)

Fares, Felix Santiago; La Sindicación de Acciones, Abeledo Perrot, Buenos Aires, 1963, (107 págs.).

Lacerda Teixeira, Egberto e José Alexandre Tavare Guerreiro; Das Sociedades Anônimas no Direito Brasileiro, José Buschatsky Editor, $2^{2}$ vol., São Paulo, 1979. 
Lamy Filho Alfredo e José Luiz Bulhōes Pedreira; A Lei Pedrol, Antonio; La Anónima Actual y la Sindicación de das $S / A$, Renovar, Rio, 1992, (885 págs.).

Leães, Luiz Gastão Paes de Barros; Comentários à Lei

$S / A, 2^{\circ}$ vol., Saraiva, São Paulo, 1978 ( 5 vols.).

Acciones, Ed Rev, de Dir. Priv, Madrid, 1969.

vol. 2, tomo I, Forense, Rio, 1978, (págs. 113 a 129).

Oppo, Giorgio; Contratti Parasociali, Ed. Dottore Francesco Vallardi, Milano, 1942, (166 págs.).
20 vol, Saraiva São Paulo, 1972 (págs. 352 a 350ós, Borsoi, Rio, 1965, § 5.314, págs. 239 a 249.

(3 vols), Forense, Rio, $2^{\mathbf{z}}$ ed, 1953 (págs. 59 a 63).
Pontes de Miranda, Tratado de Direito Privado, vol. 50,

\section{A norma jurídica como modelo}

Publicado originalmente no Recueil Dalloz 1990, Chronique, Paris, p. 199.

Antoine Jeammaud

Professor da Universidade Jean Monnet

Saint Etienne - França

Tradução de Fernando Herren Aguillar

Publicação nesta Revista autorizada pelo tradutor

1. A norma jurídica é uma "regra de conduta nas relações sociais, geral, abstrata e obrigatória, cuja sanção é assegurada pelo poder público"1. Quer se adote tal definição, quer se prefira uma variante que valorize sua vinculação a um tipo de "ordens", "comandos", "imperativos" ou ainda de "diretivas", não se contesta muito que toda regra jurídica tem por objeto uma conduta, que ela mesma impõe, proíbe ou permite. No seu campo de validade, toda ordem jurídica repartiria as ações humanas entre lícitas prescritas, positivamente permitidas ou indiferentes) e ilícitas (ações proibidas ou abstençōes de fazer o que é prescrito). Pouco importa que essa repartição de acordo com um código binário possa ser importunada pelo sentimento de um "vazio jurídico", que torna incerto o estatuto de um comportamento que se desejaria fosse explicitamente comandado, proibido ou autorizado. Ess concepção das normas jurídicas e de uma relação com as ações releva desse "senso comum teórico dos juristas"2, que fornece a matéria comum da maior parte das obras ensinamentos de introdução ao direito. Ela é recebida ou confirmada por inúmeras produçōes de teoria ou filosofia do direito, a começar pelo normativismo jurídico kelseniano. Os sociólogos que se interessam pela presença do direito nas relações sociais parecem se acomodar a essa situação, ou até mesmo fazem dela o pressuposto de uma noção demasiado sumária da efetividade (os comportamentos conformes) ou da inefetividade (os comportamentos violadores) das normas. Preocupados em desvendar as fun- ções societais do direito no coração de um modo de produção gerador de desigualdades e de dominação, os enfoques críticos não se inquietam muito em relação à sua pertinência. É verdade que, se ninguém mais denunciar no direito a vontade mascarada da classe dominante ou uma pura variedade de violência, esta visão da norma jurídica como preceito de conduta pode facilitar a demonstração de sua vocação para garantir e legitimar uma ordem social estabelecida, sempre a serviço de algumas mudanças desejadas pelos detentores do poder.

Gostaríamos, contudo, de convencer da necessidade de rejeitar essa definição. Ela peca pelo simplismo e irrealismo ao mesmo tempo. Nossa convicção é a de que se uma ordem jurídica como o direito estatal francês de nosso tempo se apresenta de início como um conjunto de normas, estas não constituem todas, bem ao contrário, regras de condutas. Trata-se no máximo de regras para ações. É nisso que elas pertencem ao gênero de normas éticas, e não em razão daquilo que seria necessariamente seu obje-

2. A ambição deste questionamento parece de início limitada. Não se pretende fornecer resposta exaustiva à questão "o que é uma norma jurídica?", mas apenas mostrar a inadequação à experiência mais banal de uma definição recebida por juristas, teóricos e filósofos do direito de diversas obediências. Este questionamento se quer modesta contribuição a essa forma de polifonia que é naturalmente a prática da teoria do direito, à medida em que esta 